Missio Ecclesiae, 6(2), Oktober 2017, 167-197

\title{
KUALIFIKASI PEMIMPIN \\ MENURUT RASUL PAULUS \\ (STUDI EKSEGETIS SURAT TITUS 1:5-9)
}

\author{
Jeny Marlin
}

\section{PENDAHULUAN}

Allah menciptakan umat manusia menurut gambar dan rupa-Nya, supaya manusia dapat bersekutu, berkomunikasi langsung dengan Tuhan sebagai Penciptanya, dan manusia dapat menjalankan tugas kepemimpinan atas semua ciptaan lain di bawah petunjuk dan sesuai dengan perintah Sang Pencipta: “... Kuasailah bumi dan taklukkanlah itu ..." (Kej. 2:18). Mengenai hal ini lebih eksplisit Octavianus dalam bukunya yang berjudul Manajemen dan Kepemimpinan Menurut Wahyu Allah memaparkan seperti berikut:

Tuhan adalah Allah yang terus giat bekerja. Kata Ia "mencipta" artinya adalah membuat, mengubah sesuatu yang baru. Membuat yang semula "tidak ada" menjadi "ada" Creatio ex nihilo. Mencipta juga berarti dari "kekacauan" menjadi "ketertiban", dari "kosong" menjadi "ada" kehidupan, dari "gelap" menjadi "terang". Inilah inti dan esensi karya penciptaan Allah yang ada dalam Kejadian 1 dan 2. Dengan "mencipta" itulah Allah menyatakan bahwa Ia "berkuasa", bahwa Ia "memerintah", bahwa Ia "pemimpin". Pemimpin sejati tidak akan membiarkan sesuatu hal berlangsung begitu saja secara mekanis, otomatis, tanpa arah, tanpa makna dan tanpa kendali. Pemimpin sejati membuat sesatu "terjadi", dan Ia membuat "terobosan". 1

Jika diperhatikan, bagaimana Allah mengawali karya-Nya dengan, "jadilah ...!" (Kej. 1:3) dan mengakhiri dengan "lihatlah!, Aku menjadikan segala sesuatu baru" (Why. 21:5). Diawali dengan "mengubah" dan diakhiri

\footnotetext{
${ }^{1}$ Petrus Octavianus, Manajemen dan Kepemimpinan Menurut Wahyu Allah, (Malang: Gandum Mas, 1986), 65, 70-71
} 
dengan "mengubah". Inilah tipologi atau model Kepemimpinan Sejati yang dapat dipelajari dan diteladani dari Sang Maha Pemimpin itu sendiri. Jadi pemimpin adalah pengendali, pendorong, penggerak dan pengubah. ${ }^{2}$

Kepemimpinan memegang peranan penting yang menentukan majumundurnya suatu organisasi, dan penentu kesuksesan kerja. ${ }^{3}$ Oleh karena di mana ada kehidupan kelompok, di situ kepemimpinan dibutuhkan untuk menata mekanisme kehidupan bersama dalam kelompok tersebut. Menjawab pertanyaan "siapa yang boleh memimpin", bukan bertolak dari kelahirannya, bakatnya, kesempatan ataupun perpaduan dari ketiga unsur ini. Sebab kekuatan ketiga unsur ini barulah menghasilkan buah yang sementara, tetapi pemimpin yang dipilih dan ditetapkan oleh Allah, itulah yang boleh memimpin, yang karyanya berbuah ${ }^{4}$ untuk kekekalan. Pemilihan dan penetapan Allah adalah syarat mutlak untuk mencari seorang pemimpin, sebab kita diciptakan bukan untuk pekerjaan yang bernilai sementara, melainkan yang bernilai kekal (Ef. 2:10). Pilihan Allah atas seorang pemimpin bukan tergantung atas materi fisik manusia, melainkan atas kehendak dan pembentukan-Nya sejak seseorang itu berada dalam kandungan ibunya.

Tanda-tanda yang menunjukkan bahwa seseorang terpanggil sebagai pemimpin Kristen ialah bahwa ia menyadari kalau Allah telah menganugerahkan kepadanya kapasitas khusus (kharisma, kemampuan/ kecerdasan, pengetahuan, pengalaman) serta adanya tanggung jawab akan tugas yang dipercayakan (menggerakkan/mempengaruhi) orang yang dipimpin guna mencapai tujuan yang telah ditetapkan. Namun seorang pemimpin Kristen bukan berarti tidak mempunyai kekurangan. Dalam Perjanjian Lama dan Perjanjian Baru, para pemimpin rohani juga didapati tidak sempurna.

Pada tahun 1999 Pdt. Roy Clements, seorang mantan pendeta Kristen Injili (Kharismatik) di Inggris, menyingkapkan keterlibatannya dalam

\footnotetext{
2 Eka Darmaputera, Kepemimpinan dalam Persfektif Alkitab, (Yogyakarta: Kairos Books), 14-15

3 Band: Kepemimpinan organisasi dapat dikatakan sebagai kepemimpinan tim, dalam hal ini Lencioni mendefinisikan kepemimpinan tim sebagai berikut: "The word team has been so overused and misused in society that it has lost much of its impact. The truth is, few groups of leaders actually work like a team, at least not the kind that is required to lead a healthy organization", dan "A leadership team is a small group of people who are collectively responsible for acbieving a common objective for their organization". Patrick M. Lencioni, The Advantage; Why Organizational Health Trumps Everything Else in Business, (San Fransisco: Published By Jossey-Bass, 2012), 20-21

${ }^{4}$ Stephen Tong, Hidup Kristen yang Berbuah, (Surabaya: Lembaga Reformed Injili Indonesia, 2001), 55
} 
hubungan homoseksual dengan seorang laki-laki. Dia mundur dari jabatannya sebagai seorang pendeta, dan berpisah dengan isterinya.

Tahun 2008 Pdt. Benny Hinn, seorang penginjil televisi dan pendeta Kharismatik tenar asal AS, didakwa bahwa dia melakukan sodomi dengan seorang pendeta senior lelaki terkenal di Kampala, ibu kota uganda. Skandal seks ini terjadi ketika Hinn mengadakan KKR di Kampala. Ketika skandal seksnya terbongkar, Suzanne, isterinya ketika mengetahui kelainan seksual suaminya mengajukan gugatan cerai di pengadilan. Hinn mengatakan gugatan perceraian ini karena "perbedaan-perbedaan yang tidak bisa didamaikan" antara dia dan isterinya, suatu frasa yang secara samar-samar mencoba menutupi skandal seks yang dia lakukan. ${ }^{5}$

Berbagai kesalahan fatal dan kegagalan seorang pemimpin Kristen menimbulkan satu pertanyaan yang memerlukan perhatian dan penelitian khusus karena kualifikasi pemimpin yang bobrok menjadi penyebab nama Tuhan dilecehkan, dunia dan gereja dianggap sampah oleh masyarakat.

Dari kasus penyimpangan di atas menunjukkan bahwa pemimpin Kristen walaupun telah melayani Tuhan dan memimpin jemaat puluhan tahun dapat jatuh dalam dosa perzinahan, salah satu penyebabnya karena kurangnya penguasaan diri sebagai pemimpin rohani, mereka membiarkan diri terbuai oleh keinginan daging mereka. J. Robert Clinton menjelaskan bahwa seorang pemimpin Kristen adalah: seorang yang mendapat kapasitas dan tanggungjawab dari Allah untuk memberi pengaruh kepada kelompok umat Allah tertentu untuk menjalankan kehendak Allah bagi kelompok tersebut. ${ }^{6}$ Tulisan Kenneth Prior yang dikutip oleh Paul Hidayat menyebutkan seperti berikut:

Bahaya-bahaya yang mengancam kepemimpinan Kristen itu ialah: "Ketidakdewasaan (Yusuf), ketidaklayakan (Musa), Pencobaan seksual (Samson, Daud, Salomo), Depresi (Elia), di bawah bayangbayang Sang Mentor (Elisa), Ketegangan hidup pernikahan (Hosea), impulsif (Petrus), cinta akan kuasa dan prestise (Yakobus dan Yohanes), oversensitivitas (Timotius), kritik (yang dialami Paulus). ${ }^{7}$

\footnotetext{
5 www.KristenSkeptis.com, “Hamba Tuhan Bermasalah”, (tanggal 11 Februari 2011), 4

${ }^{6}$ J. Robert Clinton dikutip oleh Eddie Gibbs, Kepemimpinan Gereja Masa Mendatang, (Jakarta: BPK Gunung Mulia, 2010), 19

${ }^{7}$ Paul Hidayat, Pendidikan Teologi Injili Suatu Alternatif?:Skisma Gereja dan Kualitas Kepemimpinan Kristen di Indonesia, (Malang: Tunggal Murni, 1995), 121
} 
Hal ini tentunya memicu timbulnya kegagalan seorang pemimpin dalam kepemimpinannya. Yang mengakibatkan pemimpin tersebut tidak dapat menjadi model ${ }^{8}$ bagi pemimpin yang lain, dan tidak menjadi berkat. Berkenaan dengan hal ini, Eddie Gibs memaparkan bahwa para pemimpin yang berusaha dengan kekuatan mereka sendiri untuk melakukan tugas yang menggentarkan hanya akan memperoleh kegagalan. Oleh karena itu dalam setiap langkahnya mereka memerlukan kekuatan dan tuntunan Roh Kudus. ${ }^{9}$

\section{DEFINISI ISTILAH}

Sebelum membahas tentang kualifikasi seorang pemimpin menurut teks Surat Titus 1:5-9, maka terlebih dahulu perlu memahami pengertian tentang kata pemimpin.

\section{$\underline{\text { Pengertian Kata "Pemimpin" Secara Umum }}$}

Istilah "Pemimpin" dalam "Kamus Besar Bahasa Indonesia" adalah "pemimpin sebagai perihal memimpin atau terkendali"" dan menurut "Kamus Besar Bahasa Indonesia Kontemporer" adalah: "orang yang memimpin atau orang yang memberi petunjuk." 11 Sedangkan dalam "Kamus Antropologi," pemimpin adalah "seorang atau sejumlah orang yang memerintah, menyuruh, membina dan melindungi warga masyarakat, karena kewibawaan, kekuasaan, dan wewenang yang dimilikinya berdasarkan adat-istiadat dan hukum yang berlaku dalam masyarakat yang bersangkutan."12

8 "Kata "Model" dalam kamus Ilmiah populer berarti: bentuk, ala, cara, kebiasaan, tata bentuk. Sedangkan kamus umum bahasa Indonesia sendiri menjelaskan model adalah pola, contoh, acuan, ragam." W.J.S Poerwadarminta, Kamus Umum Bahasa Indonesia, (Jakarta: Balai Pustaka, 1987), 653

${ }^{9}$ Eddie Gibbs, Kepemimpinan Gereja ..., 28

10 _ Kamus Besar Bahasa Indonesia, (Jakarta: Departemen Pendidikan dan Kebudayaan R.I., 1998), 684

${ }^{11}$ Peter Salim, Yenny Salim, Kamus Bahasa Indonesia Kontemporer, (Jakarta: Modern English Press, 1991), 1260

12 Suryono Aryanto, Kamus Antropologi, (Jakarta: Akademika Presindo, 1985), 301302 
Pemimpin adalah seseorang yang melakukan aktivitas untuk mempengaruhi orang-orang supaya diarahkan mencapai tujuan organisasi. ${ }^{13}$ Eka Darma Putra menjelaskan bahwa seorang pemimpin adalah seorang yang memotivasi, mengajak, mengarahkan, bukan menguasai, karena menguasai mempunyai arti memaksa, mengancam dan memanipulasi. Menurutnya, kepemimpinan mengandalkan "Visi dan kepercayaan", sementara "kekuasaan" mengandalkan "kekuatan dan ketakutan."

Seorang pemimpin memiliki sifat, kebiasaan, temperamen, watak dan kepribadian yang unik dan khas sehingga membedakan dirinya dengan pemimpin yang lain. Gaya atau style hidupnya akan mewarnai perilaku dan tipe kepemimpinannya.

\section{$\underline{\text { Pengertian Kata "Pemimpin" Menurut Alkitab }}$}

Alkitab Perjanjian Lama maupun Perjanjian Baru ada cukup banyak pembahasan tentang pemimpin.

\section{Menurut Perjanjian Lama}

Istilah "pemimpin" dalam Perjanjian Lama yang terjemahkan Shepherd dalam bentuk kata kerja רעי (ro'eh) artinya "menggembalakan." Terdapat kirakira 170 kali dalam Alkitab. Dalam bentuk kata benda, kata ro'eh artinya "gembala" terdapat 62 kali dalam Perjanjian Lama. Penggunaannya dipakai di mana Allah sebagai Gembala Agung yang menggembalakan, artinya memberi makanan dan memelihara kawanan domba-Nya. ${ }^{14}$ Penggunaan kata ini bagi Allah pertama kali dari diri Yakub (Kej. 49:24). Kemudian oleh Daud, dan Yesus sendiri. ${ }^{15}$ Pemahaman Sheperd Leadership juga dikenakan kepada manusia, yaitu kepada Musa dan Harun dianggap sebagai gembala Israel. Pemahaman metafora di mana shepherd dikenakan kepada raja atau pemimpin, adalah dengan konsep berpikir bahwa rajalah yang memberi makan dan memelihara rakyatnya (Yer. 23:1-2; 40:13, 41:11,13,16). Jadi raja disebut

\footnotetext{
${ }^{13}$ Miftah Thoha, Kepemimpinan dan Manajemen, (Jakarta: PT Raja Grafindo Persada, 1993), 5

${ }^{14}$ W.E. Vine, Merril F. Unger, William White, Jr., Vine's Complete Expository Dictionary of Old and New Testament Words, (Nashville: Thomas Nelson Publishers, 1984), 228

152 Sam 5: 2a -3, Band. W.E. Vine, Merril F. Unger, William White, Jr., Vine's Complete Expository Dictionary of ..., 227-228
} 
sebagai gembala bagi rakyatnya, karena dialah penguasa, yang dianggap yang memberi makan dan pemeliharaan rakyatnya. ${ }^{16}$

\section{Menurut Perjanjian Baru}

Istilah "pemimpin" dalam Perjanjian Baru memakai kata poimen artinya gembala, yang digunakan secara harafiah dan secara metafora. Dalam Matius 9:36 dan Markus 6:34, Yesus menyatakan bahwa orang Israel seperti domba tanpa gembala (poimena). Hal ini menunjukkan bahwa pemimpin diidentikkan dengan gembala. Hal yang berbeda adalah dalam Efesus 4:11, di mana metafora gembala menjadi salah satu jabatan resmi di dalam gereja di antara jabatan-jabatan lainnya misalnya imam, rasul dan nabi, dan lain-lain. Tuhan Yesus menghendaki para murid-Nya menjadi pemimpin proto (first), hendaklah ia menjadi doulos (bondman). Kedua kata ini sangat kontras, tetapi justru model utama menjadi proto adalah doulos, sebagai ciri khas pemimpin rohani. Sehubungan dengan hal ini, France menjelaskan bahwa:

Pendirian di dalam kepemimpinan yang ada adalah memiliki kualitas secara sekuler. Oleh sebab itu, tidak boleh menjadi ukuran dan diterapkan dalam kepemimpinan rohani, sehingga kekuasaan dan kebesaran yang dimiliki oleh para pemimpin rohani (para murid Yesus) seharusnya memiliki nilai yang berbeda (karena memiliki kualitas ilahi) dari cara para pemimpin dunia telah digunakan. ${ }^{17}$

Dengan demikian, pribadi Tuhan Yesus menjadi pelopor atau perintis (Ibr. 2:10; 12:2; Kis. 3:15). Tuhan Yesus Kristus adalah arkhego (pemimpin yang absolut), yaitu pemimpin yang membawa orang kepada keselamatan melalui penderitaan-Nya, memimpin kita dalam iman kepada maksud Allah, yaitu kesempurnaan yang mengarah kepada hidup kekal. Hal ini terjadi, karena Tuhan Yesus telah ditinggikan oleh Allah sendiri dengan tangan kanan-Nya menjadi pemimpin dan Juruselamat (Kis. 5:31).

Seorang pemimpin Kristen hendaknya mengenal dirinya secara baik. Dalam hal ini berkaitan dengan kepribadian, karakter seorang pemimpin

\footnotetext{
${ }^{16}$ Laird Harris (Ed.), Theological Wordbook of the Old Testament, (Chicago: Moody Press, 1980), 853

17 R.T. France, Tyndale New Testament Commentaries, Matthew, (Grand Rapids: Eerdmans, 1978), 293
} 
Kristen mengambil tempat yang sangat menentukan untuk suatu keberhasilan atau kesuksesan dalam kepemimpinannya. ${ }^{18}$ Apa yang menyebabkan seorang pemimpin itu gagal atau tidak mencapai garis finish kepemimpinannya dengan predikat baik (finishing well). Bagi penulis, semua ini terjadi oleh karena pemimpin tersebut kehilangan pengendalian diri atau penguasaan dirinya dalam menjalankan kepemimpinan tersebut. Dengan demikian natur keberdosaan manusia menjadi esensi kegagalan manusia dalam berinteraksi dengan Tuhan dan sesama. ${ }^{19}$

Hal ini terbukti di sepanjang sejarah kepemimpinan manusia di bumi ini. Segala bentuk kejahatan seperti keserakahan, kecurangan dan mementingkan diri sendiri nyata, yang adalah buah dari dosa. Berkaitan dengan ini, Octavianus mengutip pendapat Steven R. Covey dari buku "The Seven Habits of Highly Effective People," yaitu:

Realita inilah yang terjadi dalam kehidupan manusia di dunia, secara khusus di beberapa gereja dan para pemimpin gereja di negaranegara berkembang, hal ini juga relevan dengan kondisi kepemimpinan beberapa gereja di Indonesia, di mana esensi kedewasaan para pemimpin gereja yang seharusnya terfokus pada nilai kasih kepada Allah dan sesama tetapi dikuasai oleh ambisi pribadi atau kelompok. ${ }^{20}$

Kemana pun seseorang pergi, maka orang tersebut selalu diikuti oleh "musuh"-nya, inilah yang disebut "sisi gelap" (kelemahan-kelemahan) $)^{21}$ pemimpin. Hal ini dijelaskan oleh Albert L. Winseman yang dikutip oleh Gary L. McIinstosh:

Sifat yang paling penting yang harus dimiliki pemimpin seringkali sangat kurang yakni: mawas diri. Para pemimpin yang efektif seharusnya mawas diri, tidak hanya mengenali kelebihan mereka tetapi juga kelemahan - sisi gelap dari kelebihan-kelebihan yang ada.

18 Yakob Tomatala, Kepemimpinan yang Dinamis, (Malang: Gandum Mas, 2012), 30

19 Ibid

${ }^{20}$ Petrus Octavianus, Menuju Indonesia Jaya (2005-2030) dan Indonesia Adidaya (2030-2055), (Batu: Departemen Literatur YPPII, 2004), 16

${ }^{21}$ Gary L. McIintosh, Overcoming the Dark Side of Leadership, (Malang: Literatur SAAT, 2012), 23 
Tanpa mawas diri banyak pemimpin jatuh dan hancur tanpa menyadari potensi maksimal mereka bagi Kerajaan Allah. ${ }^{22}$

Agar menjadi pemimpin yang kuat bukan hanya perlu menggali talentatalenta dari Allah, tetapi juga kemampuan mengatasi faktor-faktor negatif (kelemahan-kelemahan). ${ }^{23}$ Sehubungan dengan ini Rick Warren menjelaskan bahwa:

Semua orang memiliki kelemahan dan ketidaksempurnaan fisik, emosi, intelektual dan rohani, bahkan keadaan yang tidak bisa dikendalikan yang memperlemah seseorang seperti keterbatasan dalam keuangan atau hubungan. Masalah yang lebih penting adalah apa yang harus dikerjakan dengan kelemahan-kelemahan ini. Biasanya kita menyangkali kelemahan kita, membelanya, mencari dalih untuknya, menyembunyikannya dan membencinya. Hal ini mencegah Allah menggunakannya dengan cara yang Dia inginkan, sedangkan Allah memiliki pandangan yang berbeda tentang kelemahan-kelemahan seseorang. Kelemahan-kelemahan seseorang bukanlah suatu kebetulan. Allah dengan sengaja mengijinkannya ada di dalam kehidupan seseorang dengan tujuan untuk menunjukkan kuasa-Nya. Allah memakai orang-orang biasa yang tidak sempurna untuk melakukan hal-hal yang luar biasa, walaupun mereka mempunyai berbagai kelemahan. ${ }^{24}$

\section{KUALIFIKASI PEMIMPIN MENURUT SURAT TITUS 1:5-9}

\section{$\underline{\text { Profil Titus }}$}

Surat Titus adalah salah satu surat kiriman pastoral atau surat pengembalaan yang ditulis oleh Rasul Paulus (Tit. 1:1). Titus adalah salah satu anak rohani Paulus (Tit. 1:4). Titus bertobat melalui pelayanan Paulus, hal ini terjadi sebelum sidang di Yerusalem (Kis. 15), lalu menjadi teman sekerja dan pembantu Paulus dalam pekerjaannya. Paulus meminta Titus untuk tinggal di

\footnotetext{
${ }^{22}$ Gary L. McIintosh, Overcoming the Dark Side of ..., ii

${ }^{23}$ John C. Maxwel, 21 Hukum Kepemimpinan Sejati, (Batam: Interaksara, 2004), 22

${ }^{24}$ Rick Warren, The Purpose Driven Life, (Malang: Gandum Mas, 2012), 298-300
} 
Kreta untuk mengurus jemaat di sana (Tit. 1:5). ${ }^{25}$ Kreta merupakan salah satu pulau di laut Tengah, yang sebagian besar berbukit-bukit. Orang-orang Kreta pada umumnya terkenal sebagai orang-orang yang suka berdebat dan sukar dikendalikan. Tidak seperti Timotius, Titus bukan orang Yahudi asli dan ia tidak disunat (Gal. 2:3). Titus seorang yang kuat, ramah, tulus dan begitu dipercaya oleh semua pihak dalam satu perselisihan. Ia seorang organisator dan pemimpin yang baik. Menurut Douglas ada tiga hal yang dikemukakan di dalam surat ini yaitu:

Pertama, Titus diingatkan mengenai sifat-sifat orang yang boleh menjadi pemimpin jemaat. Hal itu dikemukakan terutama karena kelakuan orang-orang di Kreta banyak yang jahat. Kedua, Titus dinasihati mengenai bagaimana seharusnya ia mengajar setiap golongan orang yang menjadi anggota jemaat itu, yaitu golongan laki-laki dan wanita yang sudah tua (yang seharusnya mengajar pula orang-orang yang lebih muda dari mereka), golongan orang-orang muda, dan golongan hamba-hamba. Akhirnya Titus diajar mengenai bagaimana seharusnya kelakuan orang Kristen. Yang paling penting ialah bahwa orang Kristen harus peramah dan suka damai, jangan membenci orang, jangan suka bertengkar atau menimbulkan perpecahan. ${ }^{26}$

\section{Analisa Konteks}

Surat Titus ditulis di Makedonia kira-kira pada tahun 66 atau 67. Surat ini membicarakan asas ajaran Kristen, pemerintahan dalam jemaat dan bagaimana Titus seharusnya bertindak terhadap anggota jemaat, terhadap yang bersalah, maupun yang tidak bersalah. Surat ini adalah surat resmi. Rupanya Paulus menghendaki agar surat ini bukan saja dibaca oleh Titus, tetapi juga oleh semua anggota jemaat. Paulus telah menetapkan Titus sebagai wakilnya di Kreta.

Titus adalah seorang Yunani dan sahabat karib Paulus. Dua kali ia menjadi utusan Paulus ke jemaat di Korintus. Ia amat setia dan sama sekali tidak mementingkan dirinya sendiri. Ia telah menyertai Paulus dan Barnabas pada waktu mereka pergi ke Yerusalem. Tituslah yang membawa surat Paulus kepada jemaat di Korintus, baik yang pertama maupun yang kedua. Oleh

\footnotetext{
${ }^{25}$ Merrill C. Tenney, Survei Perjanjian Baru, (Malang: Gandum Mas, 2000), 412

${ }^{26}$ Ibid., 592-593
} 
Paulus ia ditinggalkan di pulau Kreta supaya ia dapat menyempurnakan apa yang belum sempurna dalam jemaat itu, serta mengatur dan membangun jemaat itu. Titus juga mengangkat penatua-penatua dalam tiap-tiap jemaat seperti yang dilakukan Paulus sebelum Paulus meninggalkan pulau Kreta itu.

Titus menyertai Paulus pada waktu Paulus dipenjarakan di Roma. Dan rupanya surat Paulus ini ditulis kepada Titus sebelum Paulus dipenjarakan untuk kedua kalinya, tidak lama sebelum Rasul Paulus dibunuh. Paulus meninggalkan Titus di sana supaya ia menyempurnakan pekerjaan yang telah dimulai oleh mereka sendiri. Mungkin Titus merasa bahwa pekerjaan itu sangat sukar. Rupanya Paulus menulis surat ini bukan untuk Titus saja, melainkan untuk anggota-anggota jemaat juga. Karena pekerjaan Titus di Korintus sudah berhasil baik, maka sekarang Paulus hendak menyerahkan suatu tugas yang baru kepadanya yaitu untuk menggembalakan jemaat di pulau Kreta. Titus merupakan seorang pengabar Injil yang pergi ke berbagai tempat. Sesudah Titus menyelesaikan tugasnya di Pulau Kreta, maka pergilah ia ke Dalmatia seperti yang dikatakan dalam II Timotius 4:10. Setelah itu, Titus tidak disebut lagi dalam Alkitab. Surat ini sangat mengutamakan perbuatan-perbuatan baik yang harus dilakukan oleh orang-orang Kristen (Tit. 1:16; $2: 7,14 ; 3: 1,8,14$ ). ${ }^{27}$

Dalam surat Korintus dilaporkan bahwa Paulus dua kali mengutus Titus ke Korintus (2 Kor. 7:6; 8:16; 12:18 dst). Jelaslah bahwa ia sangat setia dan tidak mementingkan dirinya sendiri. Paulus memberi Titus tugas yang sulit, yaitu mencoba menyelesaikan masalah yang timbul dalam gereja di Korintus, dan dalam suratnya yang kedua kepada gereja itu kita mengetahui bagaimana ia diterima dengan baik di sana (2 Kor. 7:6, 7). Jelaslah bahwa Paulus menaruh kepercayaan penuh pada kemampuan Titus, ia sehati dengan Paulus dan memang Paulus menaruh kepercayaan kepadanya untuk menyempurnakan pekerjaan yang ditinggalkan Paulus "dengan maksud, supaya dia mengatur apa yang masih perlu diatur, dan supaya dia menetapkan penatua-penatua di setiap kota" (Tit. 1:5). Dengan kata lain, ia ditinggalkan di Kreta untuk memegang peranan penting dalam kepemimpinan gereja di sana (Tit. 1:5). ${ }^{28}$

Setelah selesai mengunjungi jemaat-jemaat di Makedonia, Paulus bertolak lagi ke Asia Kecil dengan mengajak Titus kali ini. Jalan yang ia tempuh ialah lewat Troas (II Tim. 4:13) ke Efesus, di mana ia menengok Timotius sesuai dengan janjinya (I Tim. 3:14). Kemudian ia pergi ke Miletus

\footnotetext{
${ }^{27}$ J. Wesley Brill, Tafsiran Surat Timotius dan Titus, (Bandung: Yayasan Kalam Hidup, 1996), $95-97$

28 Ola Tulluan, Introduksi Perjanjian Baru, (Malang: Departemen Literatur YPPII, 1999), 235
} 
(II Tim. 4:20), dan dari sana ke pulau Kreta. Di Kreta Paulus melakukan kegiatan untuk beberapa waktu lamanya, kemudian meninggalkan Titus di Pulau tersebut (Tit. 1:5), dengan tugas membina jemaat-jemaat yang baru. Paulus sendiri meneruskan perjalanannya ke Akhaya lewat Korintus (II Tim. 4:20). Ia kemudian bermukim di Nikopolis (Tit. 3:12). Dari situ ia menulis surat kepada Titus di Kreta (tahun 64) dan meminta kepadanya untuk bergabung di Nikapolis dan melanjutkan pekerjaan rasul Paulus di daerah itu. Paulus kemudian bertolak ke Roma dengan maksud untuk melaksanakan rencana Pemberitaan Injil ke Spanyol yang sekian lamanya tertunda.

Jemaat di Kreta harus benar-benar memahami "kehendak Kristus". Dalam jemaat ini proses pembaharuan ${ }^{29}$ sudah dimulai, karena telah terjadi berbagai masalah yang disebabkan oleh ulah para pengajar sesat sehingga seluruh keluarga-keluarga terjerumus di jalan yang salah.

Paulus sangat menguatirkan orang-orang Kristen di Kreta. Keadaan di Kreta sangat mengecewakan, gereja tidak terorganisasi dan tingkah laku para anggotanya sangat ceroboh. ${ }^{30}$ Mereka bagaikan domba-domba tanpa gembala. Banyak guru palsu menghantar mereka pada jalan yang salah. Para prianya lalai dan ceroboh, wanita-wanita yang tua suka bergunjing dan mabukmabukan, dan wanita-wanita mudanya malas dan genit. Meskipun Paulus mengatakan bahwa keselamatan tidak dapat diperoleh karena perbuatan baik yang mereka lakukan (3:5), ia menyatakan dengan tidak kalah tegasnya bahwa orang-orang yang percaya, memelihara perbuatan baik dengan saksama. ${ }^{31}$

Kerusuhan di Kreta ini disebabkan oleh gabungan dari kelemahan moral yang berasal dari sifat bawaan bangsa Kreta (1:12-13) dan perintah serta omongan sia-sia yang disebarluaskan oleh penganut Yudaisme, yang menyangkal Allah (1:16), tidak tertib (1:10), suka mengacau (1:11) dan hanya mencari keuntungan bagi diri sendiri (1:11). ${ }^{32}$ Tugas yang diberikan kepada Titus ialah untuk menetapkan penatua-penatua, dan mengatur hal-hal yang lain yang menyangkut ibadah jemaat (Bd. Tit. 2:11-15). Dengan kata lain, tugas Titus adalah menggembalakan dan mengatur jemaat $(1: 5-3: 11){ }^{33}$

29 "Perbaruan adalah inti kekristenan yang dinamis dan dasar yang di atasnya orangorang Kristen baik secara bersama, mapun secara Pribadi dapat mengenal Allah (Band: Rm.12:2)." Gene A Getz, Hiduplah Dalam Kekudusan..., 7

${ }^{30}$ Merrill C. Tenney, Survei Perjanjian ..., 417

31 Ibid.

${ }^{32}$ Ibid.

${ }^{33}$ Ola Tulluan, Introduksi Perjanjian ..., 236 


\section{Konteks Jauh}

Selesai mengunjungi jemaat-jemaat di Makedonia, Paulus bertolak lagi ke Asia kecil dengan mengajak Titus kali ini. Jalan yang ia tempuh ialah lewat Troas (II Tim. 4:13) ke Efesus, di mana ia menengok Timotius sesuai dengan janjinya (I Tim. 3:14). Kemudian ia pergi ke Miletus (II Tim. 4:20) dan dari sana ke pulau Kreta. Di Kreta Paulus melakkan kegiatan untuk beberapa waktu lamanya, kemudian meninggalkan Titus di pulau tersebut (Tit. 1:5) dengan tugas membina jemaat-jemaat yang baru. Paulus sendiri meneruskan perjalanannya ke Akhaya lewat Korintus (II Tim. 4:20). Ia kemudian bermukim di Nikopolis (Tit. 3:12). Dari sini ia menulis surat kepada Titus di Kreta (tahun 64) dan meminta kepadanya untuk menggabungkan diri di Nikopolis dan melanjutkan pekerjaan rasul Paulus di daerah itu. Paulus kemudian bertolak ke Roma dengan maksud untuk melaksanakan rencana Pekabaran Injil ke Spanyol yang sekian lamanya tertunda. Agaknya Titus berhasil di dalam usaha pekabaran Injil di sekitar Nikopolis, sebab ia memperluas kegiatannya ke Utara, ke wilayah Dalmatia di Yunani Barat (II Tim. 4:10). Sama seperti I, II Timotius dan Titus berisi petunjuk-petunjuk cara bagaimana menata hidup jemaat-jemaat dan menanggulangi ajaran-ajaran sesat. Ajaran-ajaran sesat yang ada di Kreta mempunyai banyak persamaan dengan yang di Efesus (I, II Timotius). ${ }^{34}$

\section{Konteks Dekat}

Kreta adalah pulau yang letaknya antara Yunani, Asia kecil dan Afrika tar. Karena letaknya yang strategis ini Kreta menjadi pusat perdagangan dan pelayaran. Paulus sendiri pernah singgah sebagai tawanan (Kis.27:7,8), tetapi waktu itu terlalu singkat untuk dapat memberitakan Injil kepada penduduknya. Ini berarti sudah ada orang-orang Kristen yang bertobat sebelum Paulus dan Titus ke Kreta (band. Kis.2:11).

Pada kunjungan Paulus di pulau Kreta pada kali pertama pasti juga sempat memberitakan Injil, sehingga baik oleh usaha orang-orang Kreta sejak Pentakosta maupun PI Paulus sendiri sekarang terdapat jemaat-jemaat Kristen di mana-mana tempat. Kesimpulan ini dapat ditarik dari ungkapan, bahwa di setiap kota perlu di angkat penatua-penatua. Memang penatua-penatua mutlak perlu untuk tiap jemaat, karena mereka harus memerintah dan mengawasi

${ }^{34}$ R. Budiman, Surat-surat Pastoral I \&II Timotius dan Titus, (Jakarta: BPK Gunung Mulia, , 2003), 125 
jemaat. Tetapi para Diaken yang mempunyai tugas untuk membantu para penatua khusus di bidang pelayanan materiil, baru diperlukan bila jemaat sudah mempunyai bentuk yang lebih konkrit. Oleh karena itu, dengan taraf perkembangan jemaat-jemaat di Kreta masih pada taraf yang rendah, dan Paulus tidak sempat menyelesaikannya, Titus ditinggalkan di sana dengan tugas supaya dapat mengatur apa yang masih perlu diatur, antara lain pengangkatan para penatua. Lebih lanjut bahwa di dalam mengangkat penatuapenatua, Titus harus mengindahkan atau memperhatikan syarat-syarat yang ditentukan Paulus bagi para penatua (ay. 6-9). ${ }^{35}$

\section{$\underline{\text { Analisa Teks Titus 1:5-9 }}$}

Dalam bagian ini penulis akan memaparkan analisa teks Titus 1:5-9 yang terdiri dari Struktur teks Titus 1:5-9, dan uraian Eksegetis Titus 1:5-9.

\section{Struktur Teks Titus 1:5-9}

Untuk memahami teks Titus 1:5-9, penulis akan membangun struktur teks. Namun terlebih dahulu penulis memaparkan pandangan teolog mengenai strukturisasi teks untuk dapat memudahkan maksud dan tujuan teks tersebut. beberapa diantaranya yaitu:

Menurut Frank E. Gaebelein, teks Titus 1:5-9 digolongkan dalam topik utama The Appointment of Qualified Elders yang dibagi dalam 2 bagian:

a. The Duties of Titus in Crete (Titus 1:5)

b. The Qualifications of the Elders (Titus 1:6-9) ${ }^{36}$

Hal yang sama juga dijelaskan oleh Kenneth dan John Kohlenberger Surat Titus 1:5-9 dijelaskan dalam satu topik The Appointment of Qualified Elders yang terdiri dari: ${ }^{37}$

1. The duties of Titus in Crete (1:5)

2. The Qualifications of the elders (1: 6-9)

${ }^{35}$ R. Budiman, Surat-surat Pastoral I \& ..., 128-129

${ }^{36}$ Frank E. Gaebelein, The Expositor's Bible Commentary, (Michigan: Zondervan Publishing House), 425

${ }^{37}$ Kenneth L. Barker \& John Kohlenberger, Zondervan NIV Bible Commentary Vol. 2 New Testament, (Grand Rapids, Michigan: Zondervant Publishing House, 1994), 922-923 
Sedangkan F.F Bruce membahas Titus 1:5-9 dibahas dalam satu topik saja yaitu: The Appointment, Qualifications and responsibilities. ${ }^{38}$

Dalam memahami struktur teks dan alur pemikiran teks Titus 1:5-9, penulis lebih menggunakan struktur teks dari Gaebelein, dan penulis mengembangkannya dengan membagi teks Titus 1:5-9 dalam dua bagian, yaitu:

1. Ayat 5 : Pentingnya penetapan Pemimpin

2. Ayat 6-9: Kualifikasi seorang Pemimpin yang:

- Tidak tercela dan mempunyai hanya satu istri (ay. 6)

- Mempunyai anak-anak yang beriman (ay. 6)

- Tak bercela/dipercaya/pelayan Tuhan (ay. 7)

- Tidak egois/tidak keras kepala/tidak angkuh (ay. 7)

- Jujur, tidak serakah/tidak tamak akan uang (ay. 7)

- Tidak suka berkelahi/tidak kejam (ay.7)

- Bukan pemabuk/kecanduan anggur (ay. 7)

- Tidak dikuasai amarah/tidak cepat marah (ay. 7)

- Dapat mengendalikan/menahan/menguasai diri (ay. 8)

- Bijaksana, benar/adil dan tulus/kudus (ay. 8)

- Mencintai keramahtamahan/suka akan yang baik (ay. 8)

- Sanggup meyakinkan para penentang (ay. 9)

- Sanggup menasihati berdasarkan ajaran yang benar (ay. 9)

- Berpegang kepada perkataan yang benar (ay. 9)

Melalui teks terjemahan bahasa Yunani, penulis akan meneliti dan mengkaji lebih dalam setiap kata dan frase yang terdapat dalam Titus 1:5-9.

\section{Uraian Eksegetis}

\section{Uraian EksegetisTitus 1:5-9}

Dalam bagian ini penulis akan memaparkan dengan akurat grammar atau tata bahasa teks Titus 1:5-9 dengan menggunakan teks terjemahan dari Perjanjian Baru Interlinear Yunani-Indonesia dan Konkordansi Perjanjian Baru (PBIK) Jilid 1.

38 F.F Bruce, The International Bible Commentary, Grand Rapids, Michigan: Zondervan Publishing House, 1979), 1493

${ }^{39}$ Hasan Sutanto, Perjanjian Baru Interlinear Yunani-Indonesia dan Konkordansi Perjanjian Baru (PBIK), (Jakarta: Lembaga Alkitab Indonesia, 2004), 1140 
Untuk memahami makna teks yang secara benar sesuai dengan grammar di atas, maka penulis membagai pembahasan eksegetis ini dalam dua bagian besar sebagaimana outline teks di atas, yaitu: Pentingnya Penetapan Pemimpin (ayat 5) dan Kualifikasi seorang pemimpin Kristen yang dapat menguasai diri (Ayat 6,7,8,9). Berikut adalah penjelasan dari teks Titus 1:5-9.

\section{Pentingnya Penetapan Pemimpin (Ayat 5)}

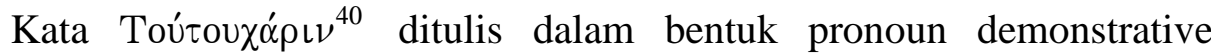
genitive neuter singular dari kata oûंo ${ }^{41}$ dan bentuk preposition genitive dari

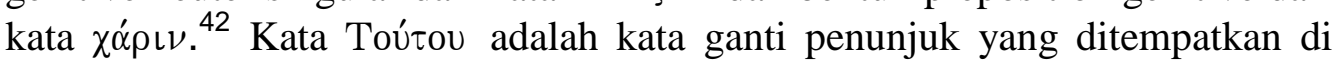
belakang kata depan $\chi \alpha \dot{\rho} \iota \nu$ diterjemahkan "untuk maksud inilah" atau For this cause/reason ${ }^{43}$ (terj. KJV/NIV). Hal ini mengindikasikan adanya "maksud atau dan tujuan" meninggalkan Titus di Kreta. Paulus dalam suratnya kepada Titus yakni menjelaskan bahwa ia "telah satu kali meninggalkan Titus di Kreta",

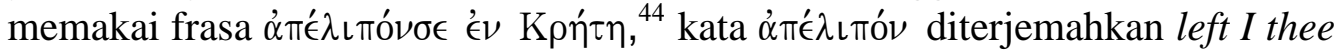
in Crete ditulis dalam bentuk indicative aorist active 1st person singular dari kata $\alpha \pi 0 \lambda \epsilon i \pi \omega$ diterjemahkan leave behind $(2 \mathrm{Ti} 4: 13,20){ }^{45}$

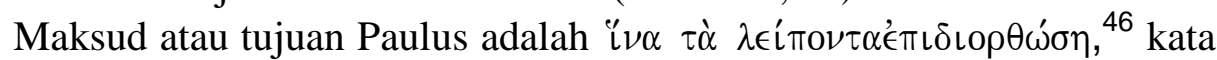

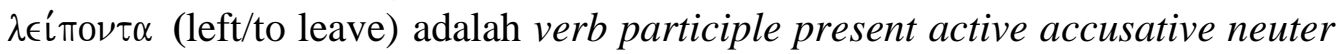

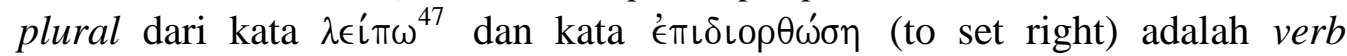

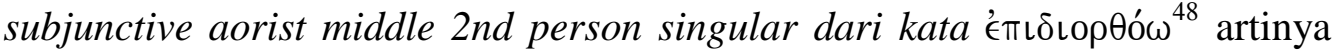
"supaya engkau (Titus) sekarang mengatur lebih baik lagi apa yang masih perlu/kurang/seharusnya diatur."

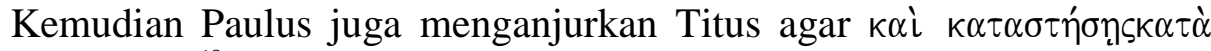

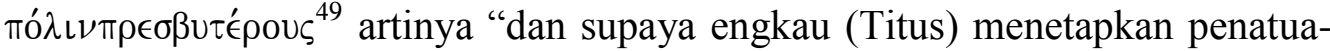

${ }^{40}$ Randy Leedy, BibleWorks New Testament ....,

41 Ibid.

${ }^{42}$ Nestle Marshal, The RSV Interlinear Greek - English New Testamen, (London: Samuel Bagster and Son Limited, 1958), 845

${ }^{43}$ Randy Leedy, BibleWorks New Testament ...,

44 Interlinear Greek - English New Testament, (Michigan: Grand Rapids Baker Book House Company, 1981), 44

${ }^{45}$ Randy Leedy, BibleWorks New Testament ...,

${ }^{46}$ Nestle Marshal, The RSV Interlinear Greek - English New Testamen ..., 845

${ }^{47}$ Randy Leedy, BibleWorks New Testament ...,

${ }^{48}$ Randy Leedy, BibleWorks New Testament ...,

${ }^{49}$ Ibid. 


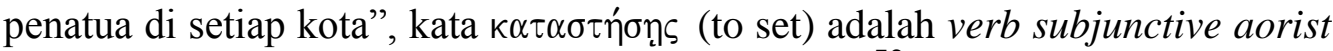

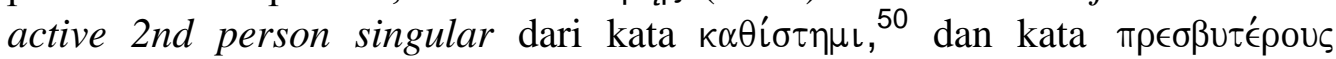
(elders: ketua/leader) adalah adjective normal accusative masculine plural comparative dari kata $\pi \rho \in \sigma \beta u ́ \tau \epsilon \rho \varsigma^{51}$, hal ini mengindikasikan bahwa Paulus dengan kesungguhan telah satu kali memohon atau menghimbau agar Titus mengatur atau menetapkan para penatua yang ditempatkan/ditugaskan sebagai ketua gereja atau pemimpin bagi jemaat yang terdapat di tiap-tiap kota.

Ayat ini diakhiri dengan frasa $\dot{\omega} \varsigma \mathfrak{\epsilon}^{\prime} \gamma \omega^{\prime}$ oo $\delta \iota \epsilon \tau \alpha \xi \alpha \dot{\alpha} \mu \eta \nu$. Kata $\delta \iota \epsilon \tau \alpha \xi \dot{\alpha} \mu \eta \nu$ (appointed, directed, command) adalah verb indicative aorist middle 1st person singular dari kata $\delta\left\llcorner\alpha \tau \alpha ́ \alpha \sigma \omega \omega^{52}\right.$ artinya "sungguh telah satu kali (Paulus) berpesan, menghimbau dan memerintahkan. Menurut Guthrie:

Titus ditugaskan ditugas Paulus untuk mengatur apa yang masih perlu diatur. Perhatikan bahwa pejabat-pejabat yang sama disebut penatu-penatua (presbyterio), yang melukiskan kedudukan sebagai "lanjut usia"; dan penilik-penilik jemaat (episkopai), menguraikan fungsinya sebagai pengawas. Masing-masing jemaat dapat mempunyai beberapa pejabat (Band. Kis. 20:17, 28). ${ }^{53}$

Barker menenguhkan pandangan di atas bahwa:

An initial duty was to "appoint elders" in each place there was a group of believers. Such plural leadership in the local congregation chose the elders with the encouragement of Titus, who in turn had the responsibility of formally appointing them to office. "As I direct you" recalls that this was ini accord with the previous orders. In this way, Titus would carry out Paul's ideal for these congregations. ${ }^{54}$

Dengan demikian, Rasul Paulus dalam suratnya kepada Titus, bermaksud mendorong dan menghimbau Titus, tentang betapa pentingnya mengatur kembali agar lebih baik lagi apa yang masih perlu/kurang/seharusnya diatur, yaitu menetapkan para pemimpin rohani yaitu para penatua yang ditempatkan atau ditugaskan sebagai ketua gereja atau pemimpin bagi jemaat yang terdapat di tiap-tiap kota.

${ }^{50}$ Randy Leedy, BibleWorks New Testament ...,

${ }^{51}$ Ibid.

${ }^{52}$ Kenneth L. Barker \&John Kohlenberger, Zondervan NIV Bible ..., 923

53 Donald Guthrie (dkk), Tafsiran Alkitab Masa Kini Jilid 3, Matius-Wahyu, (Jakarta: Yayasan Komunikasi Bina Kasih/OMF, 1999), 714

${ }^{54}$ Kenneth L. Barker \&John Kohlenberger, Zondervan NIV Bible ..., 923 


\section{Kualifikasi Penetapan Pemimpin Rohani (ay. 6-9)}

Setelah Paulus menghimbau Titus agar menetapkan para pemimpin rohani, yaitu para penatua yang ditempatkan atau ditugaskan sebagai ketua gereja atau pemimpin bagi jemaat yang terdapat di tiap-tiap kota, selanjutnya pada ayat 6-9, secara eksplisit Paulus memaparkan kepada Titus, bahwa dalam memilih, menetapkan dan menempatkan para pemimpin rohani di berbagai kota, maka ada beberapa kualifikasi atau syarat-syarat seorang pemimpin rohani, seperti berikut ini.

\section{Tidak Tercela dan Mempunyai Seorang Istri(ay. 6a)}

Paulus menyebutkan kualifikasi yang pertama bagi seorang pemimpin

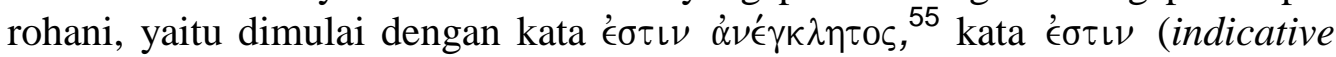
present active $3 r d$ person singular) dari kata $\epsilon i \mu \iota^{56}$ (kata ganti diri) artinya

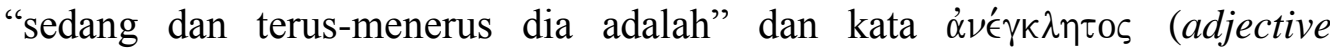
nominative masculine singular) dari kata $\alpha^{\prime} \nu \epsilon^{\prime} \gamma \kappa \lambda \eta \tau \varsigma^{57}$ diterjemahkan (KJV/NIV) unimpeachable artinya "yang tak tercela."

Jadi "pemimpin tersebut sedang dan terus-menerus adalah seorang yang

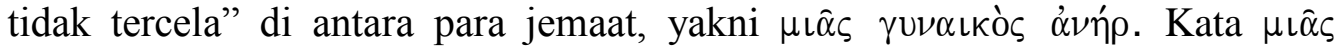

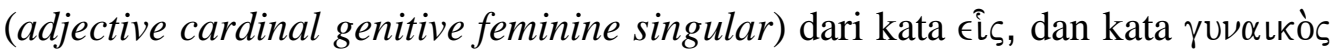

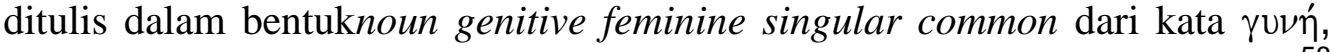

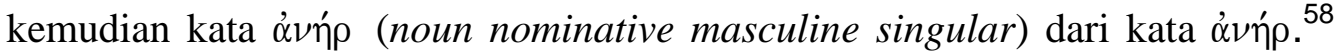
Dengan demikian ketiga kata ini mengindikasikan bahwa "seorang lakilaki/suami (memiliki) hanya satu istri (perempuan)," dalam KJV diterjemahkan husband of one wife artinya "suami dari seorang/satu istri.",59

\section{Mempunyai Anak-Anak Yang Beriman (ay. 6b)}

Pada bagian ini, Paulus menjelaskan bahwa seorang pemimpin rohani

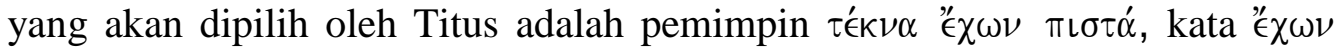
(participle present active nominative masculine singular) dari kata " $€ \chi \omega^{60}$ dilanjutkan dengan kata $\pi \iota \sigma \tau \alpha$ (adjective normal accusative neuter plural) dari

\footnotetext{
${ }^{55}$ Hasan Sutanto, Perjanjian Baru Interlinear Yunani-Indonesia..., 1141

${ }^{56}$ Randy Leedy, BibleWorks New Testament ...,

${ }^{57}$ Kenneth L. Barker \&John Kohlenberger, Zondervan NIV Bible ..., 923

${ }^{58}$ Kenneth L. Barker \&John Kohlenberger, Zondervan NIV Bible..., 923

${ }^{59}$ Randy Leedy, BibleWorks New Testament ...,

${ }^{60}$ Hasan Sutanto, Perjanjian Baru Interlinear Yunani-Indonesia..., 1141
} 
kata $\pi\left\llcorner\sigma \tau o ́ \varsigma,{ }^{61}\right.$ kedua kata ini diterjemahkan a man whose children believe/having children who believe (NIV/NAS) artinya "seorang laki-laki yang sedang mempunyai anak-anak yang percaya."

Paulus melanjutkan bahwa pemimpin rohani adalah seorang pemimpin bukan hanya memiliki anak-anak yang percaya saja, tetapi mempunyai anak-

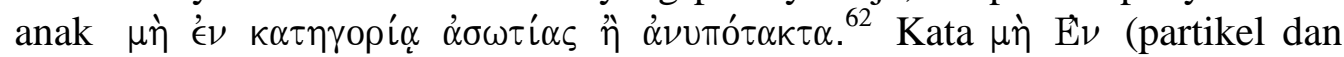
kata depan kasus datif / obyek tidak langsung) diterjemahkan not

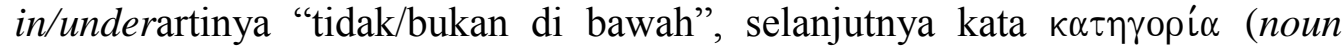

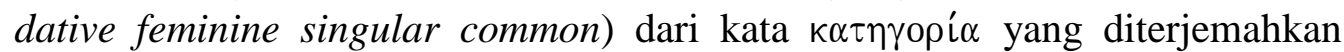
(KJV/NIV) accusation, not accused, not open to the charge of being wild ${ }^{63}$ artinya "tuduhan, tidak menuduh atau tidak terbeban menjadi liar", dan kata $\dot{\alpha} \sigma \omega \tau i \alpha \varsigma$ (noun genitive feminine singular) dari kata $\dot{\alpha} \sigma \omega \tau i \alpha,{ }^{64}$ diterjemahkan riot, profligacy, dissoluteness artinya "kekacauan, tak punya malu, tidak

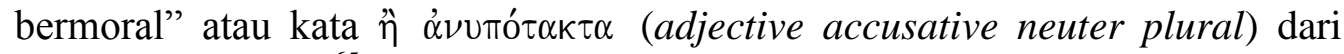
kata $\alpha \nu \cup \pi \tau_{\alpha \kappa \kappa o \varsigma}^{65}$ diterjemahkan unruly, insubordinate, disobedient, rebellion ${ }^{66}$ artinya "tak mau patuh, tak patuh, durhaka, pemberontakan." Jadi pola hidup anak-anak seorang pemimpin rohani, adalah tidak hidup dalam tuduhan/tidak hidup dalam kekacauan/hidup tidak liar, tidak punya malu, bukan tidak bermoral, atau anak-anak yang bukan tak mau patuh, tidak durhaka dan bukan pemberontak. Sebaliknya anak-anak seorang pemimpin rohani adalah anak-anak yang hidup tertib, tahu malu, bermoral, patuh, menjaga nama baik keluarga dan menghormati orang tua.

\section{Tak Bercela dan Dipercaya Untuk Melayani Tuhan (ay. 7)}

Dalam teks ini, Paulus menjelaskan bahwa seorang pemimpin rohani

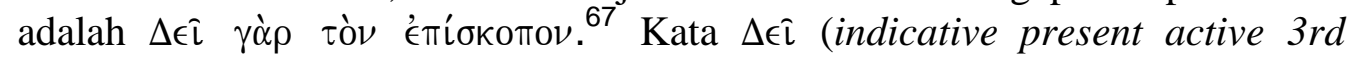
person singular) dari kata $\delta \in \hat{\imath}$ diikuti dengan kata yò $\rho$ diterjemahkan for it behoves, it is neccesary 68 artinya "untuk itu (dia) sedang dan terus-menerus

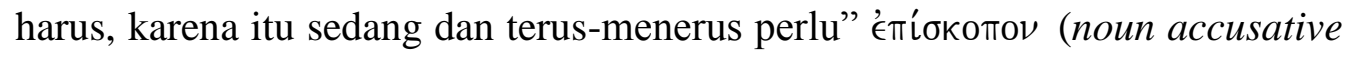

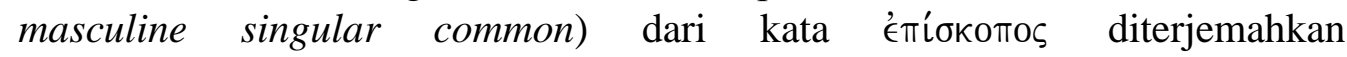

\footnotetext{
${ }^{61}$ Hasan Sutanto, Perjanjian Baru Interlinear Yunani-Indonesia..., 1141

${ }^{62}$ Randy Leedy, BibleWorks New Testament...,

${ }^{63}$ Ibid.

${ }^{64}$ Kenneth L. Barker \& John Kohlenberger, Zondervan NIV Bible ..., 923

65 Ibid.

${ }^{66}$ Randy Leedy, BibleWorks New Testament...,

${ }^{67}$ Kenneth L. Barker \& John Kohlenberger, Zondervan NIV Bible ..., 923

68 Ibid.
} 
superintendent, ${ }^{69}$ supervisor ${ }^{70}$ artinya "(seorang) pengawas." Jadi seorang pemimpin rohani adalah dia sedang dan terus-menerus harus tetap menjadi pengawas jemaat.

Selanjutnya, seorang pemimpin rohani yaitu pengawas adalah

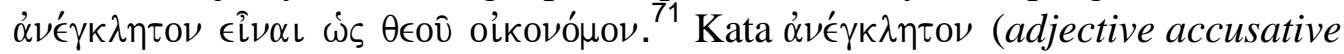
masculine singular) dari kata $\alpha^{\prime} \dot{\epsilon}^{\prime} \gamma \kappa \lambda \eta \tau ం \varsigma$ diterjemahkan blameless, irreproachable artinya "suci, tidak tercela" dan kata $\epsilon \hat{\imath} \nu \alpha \iota$ ditulis dalam bentuk infinitive present active dari kata $\epsilon i \mu$ í diterjemahkan to be artinya "menjadi

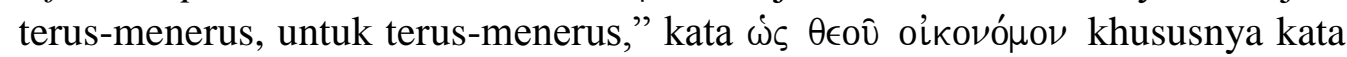

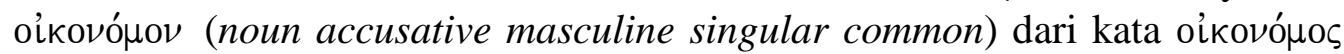
diterjemahkan steward artinya "pelayan." Jadi seorang pemimpin rohani adalah pengawas jemaat yang sedang dan terus-menerus hidup suci dan tidak bercela, tetapi dia juga menjadi sedang dan terus-menerus must be above reproach as God's steward artinya "harus sempurna seperti pelayan Tuhan" atau is entrusted with God's work artinya "dipercayakan pekerjaan Tuhan."

\section{Tidak Egois, Tidak Keras Kepala dan Tidak Angkuh (ay. 7)}

Kata $\mu \grave{\eta}$ sebagai partikel dari kata $\mu \eta^{72}$ diterjemahkan (NIV/KJV) artinya "tidak/bukan" (sebagai sanggahan) untuk kata $\alpha$ $\theta \dot{\alpha} \delta \eta$ (adjective normal accusative masculine singular) dari kata $\alpha \dot{\theta} \theta \alpha \dot{\delta} \eta \varsigma^{73}$ diterjemahkan self-pleasing, stubborn, arrogant ${ }^{74}$ diterjemahkan "memuaskan diri sendiri, keras kepala, angkuh." Jadi maksud Paulus dalam teks ini ialah, bahwa sifat yang dimiliki oleh seorang pemimpin rohani adalah "bukan seorang yang memuaskan diri sendiri, bukan seorang yang keras kepala dan bukan seorang yang angkuh." Hal ini identik terlihat jelas dengan karakter atau temperamen seseorang dalam memimpin demi kepentingan orang banyak, yang bersedia menerima kritik atau teguran dan yang rendah hati atau tidak sombong.

\section{Tidak Dikuasai Amarah/Tidak Cepat Marah (ay. 7)}

\footnotetext{
${ }^{69}$ Kenneth L. Barker \& John Kohlenberger, Zondervan NIV Bible ..., 923

${ }^{70}$ Randy Leedy, BibleWorks New Testament ...,

${ }^{71}$ Kenneth L. Barker \& John Kohlenberger, Zondervan NIV Bible ..., 923

${ }^{72}$ Ibid.

${ }^{73}$ Randy Leedy, BibleWorks New Testament ...,

${ }^{74}$ Donald Guthrie (dkk), Tafsiran Alkitab Masa Kini Jilid 3 ..., 174
} 
Selanjutnya dalam ayat 7 ini, terdapat kata $\mu \grave{\eta}$ ó $\rho \gamma^{\prime} \lambda o \nu,{ }^{75}$ kata $\mu \grave{\eta}$ artinya "tidak/bukan" yang merupakan sanggahan bersifat negatif untuk kata

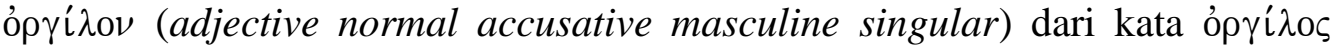
diterjemahkan (NIV/NAS) inclined to anger, quick-tempered, not soon angry (KJV), artinya keseluruhan frase ini adalah seorang pemimpin rohani memiliki sifat yaitu: bukan seorang yang dikuasai kemarahan/pemarah, seorang yang tidak berdarah panas dan seorang yang tidak cepat marah." Jadi seorang yang dipilih dan ditetapkan oleh Titus yang layak menjadi pemimpin rohani adalah bukan seorang pemimpin yang dikuasai kemarahan/pemarah, berdarah panas dan cepat marah, tetapi pemimpin yang mampu menundukkan kemarahan, panjang sabar, dan lemah-lembut. ${ }^{76}$

\section{Bukan Pemabuk/Kecanduan Anggur (ay. 7)}

Pada bagian ini, Paulus juga menyebutkan bahwa seorang pemimpin

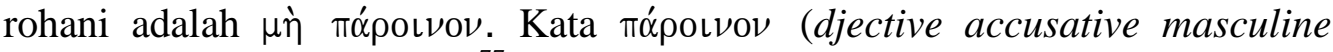
singular) dari kata $\pi \alpha \dot{\rho} \rho\left\llcorner\nu \circ \varsigma^{77}\right.$ diterjemahkan drunken, addicted wine, given to drunkenness ${ }^{78}$ artinya "mabuk, kecanduan anggur, diberikan keadaan mabuk." Artinya keseluruhan frase ini adalah: tidak suka mabuk, tidak kecanduan anggur dan tidak dalam keadaan mabuk. Jadi maksud Paulus adalah, seorang pemimpin rohani hidupnya tidak mengkomsumsi minuman keras seperti anggur yang membuat dia mabuk, karena akan kecanduan, sehingga hidupnya dikuasai oleh kemabukan. Tetapi sebaliknya seorang pemimpin rohani memiliki hidup yang senantiasa menjaga tubuhnya dalam kesucian dan kekudusan.

\section{Tidak Suka Berkelahi dan Tidak Kejam (ay. 7)}

Pada frase ini Paulus menjelaskan bahwa seorang pemimpin yang akan dipilih dan ditetapkan Titus adalah seorang yang $\mu \grave{\eta} \pi \lambda \eta^{\prime} \kappa \tau \eta \nu$. Kata $\pi \lambda \eta \dot{\kappa} \kappa \tau \eta \nu$ (noun accusative masculine singular) dari kata $\pi \lambda \eta \kappa \tau \eta \varsigma^{79}$ diterjemahkan pugnacious man, bully, violent ${ }^{80}$ artinya "suka berkelahi, pemarah, kejam." Jadi arti kata $\mu \grave{\eta} \pi \lambda \dot{\eta} \kappa \tau \eta \nu$ adalah seorang yang tidak suka berkelahi, tidak pemarah dan seorang yang tidak kejam. Paulus menegaskan bahwa seorang

\footnotetext{
${ }^{75}$ Randy Leedy, BibleWorks New Testament ...,

${ }^{76}$ Randy Leedy, BibleWorks New Testament ...,

${ }^{77}$ Frank E. Gaebelein, The Expositor's Bible ..., 1982

${ }^{78}$ Donald Guthrie (dkk), Tafsiran Alkitab Masa Kini Jilid 3 ..., 174

${ }^{79}$ Randy Leedy, BibleWorks New Testament ...,

${ }^{80}$ Frank E. Gaebelein, The Expositor's Bible Commentary Vol. II ..., 1982
} 
pemimpin rohani adalah seorang yang tidak suka berkelahi, tidak pemarah dan seorang yang tidak kejam, melainkan seorang yang suka damai, pembawa damai, lemah-lembut atau baik.

\section{Jujur, Tidak Serakah dan Tidak Tamak akan Uang (ay. 7)}

Dalam frase terakhir dari ayat 7 ini, Paulus menegaskan bahwa seorang pemimpin adalah seorang yang $\mu \grave{\eta} \alpha \grave{\imath} \chi \rho \circ \kappa \epsilon \rho \delta \hat{\eta}$. Kata $\alpha \iota \sigma \chi \rho о \kappa \epsilon \rho \delta \eta$ (adjective

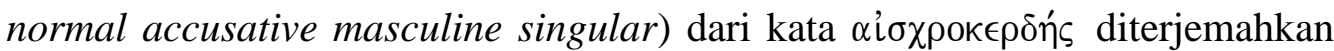
pursuing dishonest gain (NIV), fond of dishonest gain, greedy for money ${ }^{81}$ artinya "mengejar keuntungan yang tak jujur, gemar akan keuntungan tak jujur, tamak untuk uang", kata ini juga terdapat dalam 1 Timotius 3:8. Jadi arti dari kata $\mu \grave{\eta} \alpha \grave{\iota \chi \rho о к \epsilon \rho \delta \eta ~ a d a l a h ~ s e o r a n g ~ y a n g ~ t i d a k ~ m e n g e j a r ~ k e u n t u n g a n ~ y a n g ~ t a k ~}$ jujur, tidak gemar akan keuntungan tak jujur dan tidak tamak untuk uang. Dengan demikian, Paulus menekankan kepada Titus bahwa, seorang pemimpin rohani adalah seorang yang jujur atau tidak tamak akan uang dan tidak berlaku curang atau serakah.

\section{Mencintai Keramahtamahan dan Suka akan yang Baik (ay. 8a)}

Pada ayat 8 ini merupakan kelanjutan dari ayat-ayat sebelumnya yang diawali dengan kata $\dot{\alpha} \lambda \lambda \dot{\alpha} \phi\left\llcorner\lambda o^{\prime} \xi \in \nu \nu .{ }^{82}\right.$ Kata $\phi\llcorner\lambda o ́ \xi \in \nu o \nu$ (adjective normal accusative masculine singular) dari kata $\phi \iota \lambda o ́ \xi \in \nu \circ \varsigma$ diterjemahkan hospitable, hospitality artinya "ramah, keramahtamahan juga terdapat dalam 1 Timotius 3:2; 1 Petrus 4:9. Jadi yang dimaksud dengan kata $\alpha \lambda \lambda \lambda \dot{\alpha} \phi\llcorner\lambda o ́ \xi \in \nu o \nu$ adalah: But a lover of hospitality, Rather he must be hospitable artinya seorang yang mencintai keramahtamahan atau ia harus ramah dalam kepemimpinannya.

Dilanjutkan dengan kata $\phi \iota \lambda \alpha ́ \gamma \alpha \theta \mathrm{ov}$ (adjective normal accusative masculine singular) dari kata $\phi\llcorner\lambda \alpha \gamma \gamma \alpha \theta$ os diterjemahkan loving what is good, ${ }^{83}$ one who loves what is good, ${ }^{84}$ a lover of good artinya penuh kasih yang baik, seorang yang mencintai yang baik, seorang pecinta tentang hal-hal yang baik. Jadi maksud Paulus dengan kata $\phi \iota \lambda \alpha \alpha_{\alpha} \alpha \theta \nu$ adalah bahwa seorang pemimpin rohani ialah seorang yang ramah, penuh kasih dan kebaikan dan yang mencintai kebaikan serta suka akan hal-hal yang baik dalam masa kepemimpinannya.

\section{Bijaksana, Benar/Adil dan Tulus/Kudus (ay. 8b)}

\footnotetext{
${ }^{81}$ Randy Leedy, BibleWorks New Testament ...,

82 Ibid.

83 Ibid.

${ }^{84}$ Frank E. Gaebelein, The Expositor's Bible Commentary Vol. II ..., 1982
} 


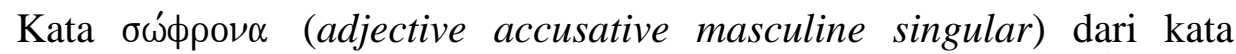
$\sigma \omega ́ \phi \rho \omega \nu^{85}$ diterjemahkan prudent, thoughtful, sober, discreet, sensible ${ }^{86}$ artinya

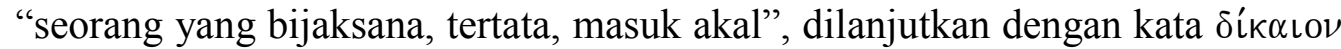

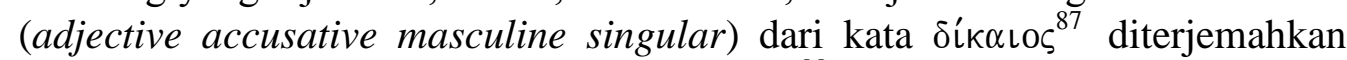
law-abiding, upright, right, just, righteous ${ }^{88}$ artinya "seorang yang taat terhadap hukum, tegak lurus, benar, adil (saleh/adil)", dan kata öøıov (adjective accusative masculine singular) dari kata ö $\sigma\left\llcorner\varsigma^{89}\right.$ diterjemahkan devout, pleasing to God, holy artinya "tulus, memuaskan ke Tuhan, kudus" juga terdapat dalam 1 Timotius 2:8. Jadi maksud Paulus dengan frase $\sigma \omega ́ \phi \rho o v \alpha$,

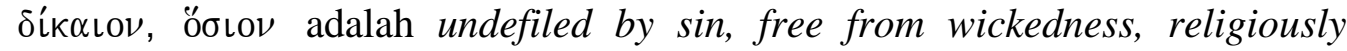
observing every moral obligation, pure holy, pious bahwa, seorang pemimpin rohani ialah seorang yang bijaksana, tertata, masuk akal, seorang yang taat terhadap hukum, jujur, benar, adil dan seorang yang tulus, memuaskan ke Tuhan, taat, bermoral dan yang kudus.

\section{Yang Dapat Mengendalikan/Menahan/Menguasai Diri (ay. 8c)}

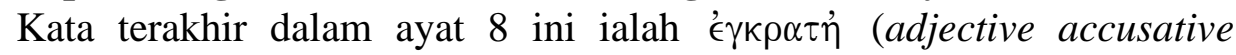

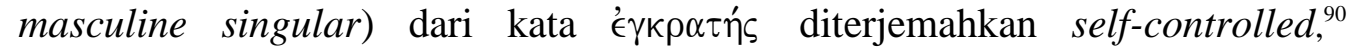
temperate ${ }^{91}(\mathrm{KJV})$ having power over, possessed of, mastering, controlling, curbing, restrainin; ${ }^{92}$ in full control of oneself, ${ }^{93}$ disciplined ${ }^{94}$ artinya "diri yang dikendalikan; dengan kepala dingin; penguasaan, mengendalikan, menahan, mengendalikan; dalam kendali dirinya penuh; menertibkan diri."

Kata ${ }^{\prime} \gamma \gamma \kappa \rho \alpha \tau \eta$, atau ${ }^{\prime} \gamma \gamma \kappa \rho \alpha \tau \eta \dot{~} \varsigma^{95}$ (engkrates), merupakan satu kata sifat yang berkasus akusatif yang memiliki arti yang dapat menguasai diri. Gaebelein juga berpendapat bahwa: "self-controlled", in control of his mind and emotions so that he can act rationally and discreetly, a virtue much needed on crete and one stressed in the Pastorals (1 Tim. 2:9,15; 3:2; 2 Tim. 1:7;

\footnotetext{
${ }^{85}$ Randy Leedy, BibleWorks New Testament ...,

${ }^{86}$ Randy Leedy, BibleWorks New Testament...,

${ }^{87}$ Ibid.

${ }^{88}$ Frank E. Gaebelein, The Expositor's Bible Commentary Vol. II ..., 1982

${ }^{89}$ Ibid.

${ }^{90}$ Randy Leedy, BibleWorks New Testament ...,

${ }^{91}$ Ibid.

${ }^{92}$ Ibid.

${ }^{93}$ Donald Guthrie (dkk), Tafsiran Alkitab Masa Kini Jilid 3 ..., 174

${ }^{94}$ Ibid.

${ }^{95}$ Barclay M. Newman Jr., Kamus Yunani-Indonesia, (BPK Gunung Mulia: Jakarta),
} 
Titus 2:2,4,5,6,12). ${ }^{96}$ Atau "self-controlled", sanggup menguasai emosi dan pikirannya sedemikian, sehingga ia dapat bertindak secara rasional dan dengan hati-hati, hal ini sangat dibutuhkan oleh seorang pemimpin jemaat.

Jadi maksud Paulus adalah seorang pemimpin rohani yang mampu mengendalikan/menahan/menguasai dirinya, selalu berkepala dingin dan penuh dengan pengendalian diri secara total ketika menghadapi apa pun dan dalam segala situasi apapun, hal ini terlihat dalam kepemimpinannya.

\section{Berpegang Kepada Perkataan yang Benar (ay. 9)}

Dalam ayat 9 ini, Paulus menegaskan tentang syarat atau ketegori sifat pemimpin yang akan dipilih dan ditetapkan oleh Titus yang terlihat dalam frase

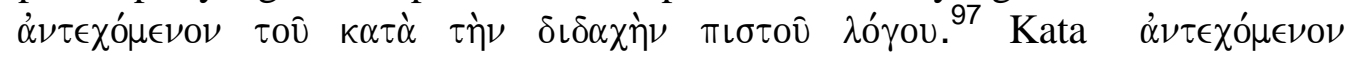
(participle present middle accusative masculine singular) dari kata $\alpha \nu \tau \epsilon \in \chi \omega$ diterjemahkan holding, artinya "yang terus-menerus berpegang, melakukan,

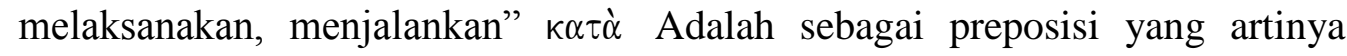

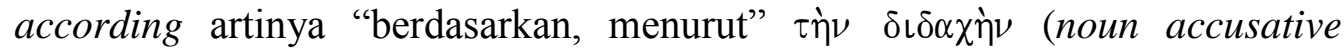
feminine singular) dari kata $\delta\left\llcorner\delta \alpha \chi \eta^{\prime 98}\right.$ diterjemahkan teaching as an activity

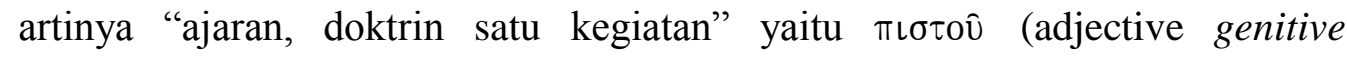

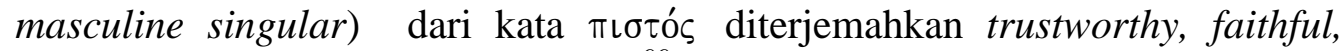
dependable, inspiring trust or faith" artinya "dapat dipercaya/jujur/handal, setia/taat, dapat diandalkan, menginspirasi kepercayaan/keyakinan atau iman“

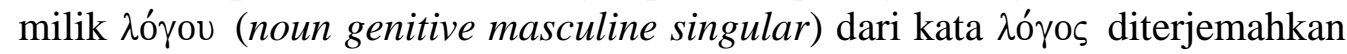
a word, the word, artinya "sebuah kata/perkataan, Firman." Jadi yang Paulus

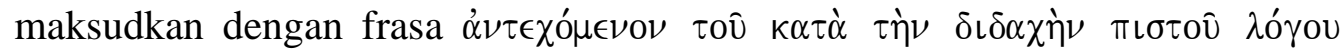
adalah holding fast the faithful word which is in accordance with the teaching (NAS) artinya "seorang pemimpin yang terus-menerus dapat dipercaya/jujur/handal, setia/taat, iman/keyakinan, dapat diandalkan dan berpegang, melakukan, melaksanakan atau menjalankan dengan iman dan keyakinan berdasarkan/sesuai ajaran/doktrin Firman Tuhan."

\section{Sanggup Menasihati Berdasarkan Ajaran Yang Benar (ay. 9)}

Selanjutnya, Paulus dalam teks ini menghimbau Titus, ketika memilih dan menetapkan pemimpin selain bepegang pada perkataan yang benar, tetapi

\footnotetext{
${ }^{96}$ Frank E. Gaebelein, The Expositor's Bible Commentary Vol. II ..., 1982

${ }^{97}$ Randy Leedy, BibleWorks New Testament ...,

${ }^{98}$ Ibid.

99 Ibid.

${ }^{100}$ Randy Leedy, BibleWorks New Testament ...,
} 


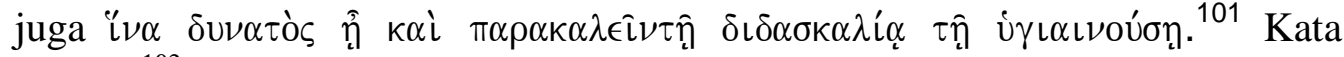

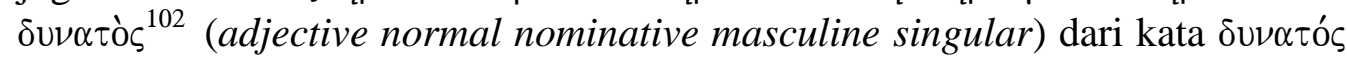
diterjemahkan powerful, strong, mighty, able (that he may be able) diterjemahkan "kuat/berkuasa, erat/tangguh, sangat kuat, sanggup/mampu" untuk $\pi \alpha \rho \alpha \kappa \alpha \lambda \epsilon \hat{\imath} \nu$ (infinitive present active) dari kata $\pi \alpha \rho \alpha \kappa \alpha \lambda \epsilon \epsilon \omega$ diterjemahkan to beseech, urge, to exhort, comfort artinya "untuk terusmenerus menenangkan" $\delta\llcorner\delta \alpha \sigma \kappa \alpha \lambda i \alpha$ (noun dative feminine singular) dari kata $\delta\llcorner\delta \alpha \sigma \kappa \alpha \lambda i \alpha$ diterjemahkan teaching, doctrin (in sound doctrine) artinya

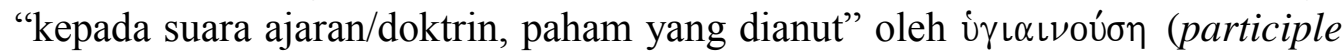

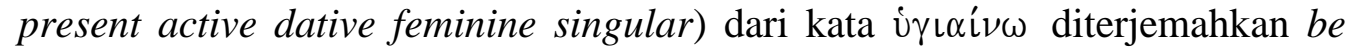
sound or correct artinya "yang terus-menerus menjadi bersuara/berbunyi atau untuk terus-menerus mengoreksi/ membetulkan." Jadi pemimpin yang Paulus

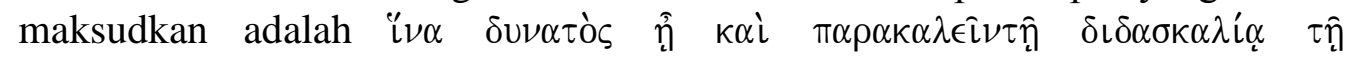

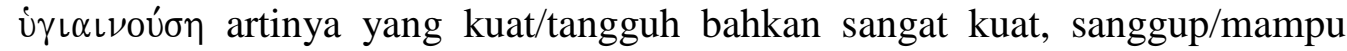
untuk terus-menerus menenangkan (suara) ajaran/paham yang terus-menerus mengoreksi iman/keyakinan pemimpin tersebut."

\section{Sanggup Meyakinkan Para Penentang(ay. 9)}

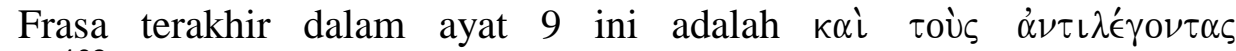

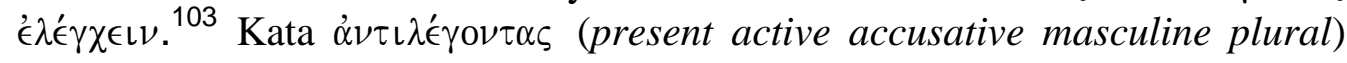
dari kata $\dot{\alpha} \nu \tau \iota \lambda \hat{\epsilon}^{\prime} \gamma \omega$ diterjemahkan to speak against, contradict, appose artinya "untuk terus-menerus berbicara/berkata kepada para pelawan, para pembantah/penyangkal, para pembangkang/penentang” yang 'є $\lambda \dot{\epsilon} \gamma \chi \in \iota \nu$ (infinitive present active) dari kata $\epsilon^{\prime} \lambda \epsilon^{\prime} \gamma \chi \omega$ diterjemahkan convict, toconvince, reprove, contradict artinya "yang terus-menerus meminta bukti/pembuktian, yang terus-menerus menghalangi, dan yang terus-menerus membantah/menyangkal. Jadi pemimpin yang dimaksud Paulus adalah pemimpin yang terus-menerus berbicara kepada para pelawan, para pembantah/para penyangkal/para penentang yang terus-menerus menyangkal/membantah/menghalangi dan meminta bukti/pembuktian, tentang keyakinan iman, ajaran iman kepercayaan yang diyakini oleh seorang pemimpin rohani.

\footnotetext{
${ }^{101}$ Randy Leedy, BibleWorks New Testament ...,

102 B.F. Drewes, Wilfrid Haubeck, Heinrich von Siebenthal, Kunci Bahasa Yunani Perjanjian Baru, Surat Roma Hingga Wahyu, (Jakarta: BPK Gunung Mulia, 2012),

${ }^{103}$ Randy Leedy, BibleWorks New Testament...,
} 


\section{SIMPULAN}

Dari hasil analisa eksegetis Titus 1:5-9, penulis menyimpulkan bahwa: Titus bukan orang Yahudi, namun menjadi satu tim dalam pelayanan Rasul Paulus, dan ditugaskan di Pulau Kreta untuk memelihara jemaat di sana. Rasul Paulus dalam suratnya kepada Titus, bermaksud mendorong dan menghimbau Titus, tentang betapa pentingnya mengatur kembali agar lebih baik lagi apa yang masih perlu/kurang/seharusnya diatur, yaitu menetapkan para pemimpin rohani yaitu para penatua yang ditempatkan atau ditugaskan sebagai ketua gereja atau pemimpin bagi jemaat. yang terdapat di tiap-tiap kota, $\mathrm{m}$

1) Pemimpin yang sedang dan terus-menerus tidak tercela" di antara para jemaat dan suami dari seorang/satu istri saja.

2) Pemimpin yang mempunyai anak-anak yang beriman, yang memiliki pola hidup anak-anak seorang pemimpin rohani, tidak hidup dalam tuduhan/tidak hidup dalam kekacauan/hidup tidak liar, tidak punya malu, bukan tidak bermoral, atau anak-anak yang bukan tak mau patuh, tidak durhaka dan bukan pemberontak. Sebaliknya anak-anak seorang pemimpin rohani adalah anak-anak yang hidup tertib, tahu malu, bermoral, patuh, menjaga nama baik keluarga dan menghormati orang tua.

3) Seorang pemimpin rohani adalah pengawas jemaat yang sedang dan terusmenerus hidup suci dan tidak bercela, tetapi dia juga menjadi sedang dan terus-menerus menjadi (must be above reproach as God's steward), artinya "harus sempurna seperti pelayan Tuhan" atau is entrusted with God's work artinya "dipercayakan pekerjaan Tuhan.

4) Seorang pemimpin rohani adalah "bukan seorang yang memuaskan diri sendiri, bukan seorang yang keras kepala dan bukan seorang yang angkuh." Hal ini identik terlihat jelas dengan karakter atau temperamen seseorang dalam memimpin demi kepentingan orang banyak, yang bersedia menerima kritik atau teguran dan yang rendah hati atau tidak sombong.

5) Pemimpin rohani adalah bukan seorang pemimpin yang dikuasai kemarahan/pemarah, berdarah panas dan cepat marah, tetapi pemimpin yang mampu menundukkan kemarahan, panjang sabar, dan lemah-lembut.

6) Seorang pemimpin rohani hidupnya tidak mengkomsumsi minuman keras seperti anggur yang membuat dia mabuk, karena akan kecanduan, sehingga hidupnya dikuasai oleh kemabukan. Tetapi sebaliknya seorang pemimpin rohani memiliki hidup yang senantiasa menjaga tubuhnya dalam kesucian dan kekudusan. 
7) Seorang pemimpin rohani adalah seorang yang tidak suka berkelahi, tidak pemarah dan seorang yang tidak kejam, melainkan seorang yang suka damai, pembawa damai, lemah-lembut atau baik.

8) Seorang pemimpin rohani adalah seorang yang jujur atau tidak tamak akan uang dan tidak berlaku curang atau serakah.

9) Pemimpin rohani ialah seorang yang ramah, penuh kasih dan kebaikan dan yang mencintai kebaikan serta suka akan hal-hal yang baik dalam masa kepemimpinannya.

10) Seorang pemimpin rohani ialah seorang yang bijaksana, tertata, masuk akal, seorang yang taat terhadap hukum, tegak lurus, benar, adil dan seorang yang tulus, memuaskan ke Tuhan, taat, bermoral dan yang kudus.

Dari simpulan di atas, berikut rekomendasi penulis:

1) Seorang pemimpin rohani hendaklah mampu mengendalikan/menahan/ menguasai dirinya, selalu berkepala dingin dan penuh dengan pengendalian diri secara total ketika menghadapi apa pun dan dalam segala situasi apa pun, hal ini terlihat dalam kepemimpinannya.

2) Seorang pemimpin hendaklah terus-menerus dapat dipercaya/jujur/handal, setia/taat, iman/keyakinan, melakukan, melaksanakan atau menjalankan dengan iman dan keyakinan berdasarkan/sesuai ajaran/doktrin perkataan/Firman Tuhan.

3) Pemimpin harus kuat/tangguh, sanggup/mampu untuk terus-menerus menenangkan (suara) ajaran/paham yang terus-menerus mengoreksi iman/keyakinan pemimpin tersebut.

4) Pemimpin mutlak harus selalu menjaga persekutuan pribadi dengan Tuhan, karena akan membawa mereka pada tingkat mawas diri atau mampu menguasai diri. Tidak dapat ditawar lagi seorang pemimpin adalah seorang yang harus mengutamakan kehidupan kerohaniannya dalam kepemimpinannya. 


\section{DAFTAR PUSTAKA}

Aryanto, Suryono,

1985 Kamus Antropologi. Jakarta: Akademika Presindo

Barker, Kenneth L. \& Kohlenberger, John, 1994 Zondervan NIV Bible Commentary Vol. 2 New Testament. Grand Rapids, Michigan: Zondervant Publishing House

Barclay, M. Newman Jr., t.t Kamus Yunani-Indonesia. Jakarta: BPK Gunung Mulia

Boeker, T.G.R. 1992 Bahasa Ibrani. Batu: Sekolah Tinggi Theologia "I-3"

Brill, J. Wesley

1996 Tafsiran Surat Timotius dan Titus. Bandung: Yayasan Kalam Hidup

Bruce, F.F

1979 The International Bible Commentary. Grand Rapids, Michigan: Zondervan Publishing House

Budiman, R.

2003 Surat-surat Pastoral I \&II Timotius dan Titus. Jakarta: BPK Gunung Mulia

1984 Tafsiran Surat-surat Pastoral. Jakarta: BPK Gunung Mulia

Caram, Paul G.

2003 Kekristenan Sejati. Jakarta: Nafiri Gabriel

Darmaputera, Eka

t.t Kepemimpinan Dalam Persfektif Alkitab. Yogyakarta: Kairos Books

Echols, Jhon M. \& Shadily, Hassan

1996 Kamus Inggris-Indonesia. Jakarta: Gramedia 
France, R.T.

1978 Tyndale New Testament Commentaries Matthew. Grand Rapids: Eerdmans

Gaebelein, Frank E.

t.t The Ekspositor's Bible Commentary. Michigan: Zondervan Publishing House

Gibbs, Eddie

2010 Kepemimpinan Gereja Masa Mendatang. Jakarta: BPK Gunung Mulia

Gunarsa, Singgih D.

2004 Bunga Rampai Psikologi Perkembangan. Jakarta: PT BPK Gunung Mulia

2004 Bunga Rampai Psikologi Perkembangan dari Anak Sampai Usia Lanjut. Jakarta: BPK Gunung Mulia

Gunawan, Adi W. Dan Setyono, Ariesandi

2007 Manage Your Mind For Succes, (Jakarta: Gramedia Pustaka Umum

Guralnik, David B.

1967 Webster's New World Dictionary. California: State Departement of Education

Harris, Laird (Ed.)

1980 Theological Workbook of Old Testament. Chicago: Moody Press

Harrison, Everett F.

1960 Baker's Dictionary of Theology, (Grand Rapids, Michigan: Baker Book House 
Hidayat, Paul

1995 Pendidikan Teologi Injili Suatu Alternatif?:Skisma Gereja dan Kualitas Kepemimpinan Kristen Di Indonesia. Malang: Tunggal Murni

Leeds, Randy

2006 Bible Works 7, Old Testament, Agustus 2006, [c:Iprogram files(x86) \bibleworks 7linitlbw700.swc.]

Lencioni, Patrick M.

2012 The Advantage; Why Organizational Healt Trumps Everything Else In Business. San Fransisco: Published By Jossey-Bass

Maxwel, John C.

200421 Hukum Kepemimpinan Sejati. Batam: Interaksara

Mclintosh, Gary L.

2012 Overcoming the Dark Side of Leadership. Malang: Literatur SAAT

Ottley, R.L.

2005 Ensiklopedi Alkitab Masa Kini Jilid I A-I. Jakarta: Yayasan Komunikasi Bina Kasih/OMF

Octavianus, Petrus

2004 Menuju Indonesia Jaya (2005-2030) dan Indonesia Adidaya (2030-2055). Batu: Departemen Literatur YPPII

1986 Manajemen dan Kepemimpinan Menurut Wahyu Allah. Malang: Gandum Mas

Poerwadarminta, W.J.S

1987 Kamus Umum Bahasa Indonesia. Jakarta: Balai Pustaka

Salim, Peter \& Salim, Yenny 
Missio Ecclesiae, 6(2), Oktober 2017, 167-197

1991 Kamus Bahasa Indonesia Kontemporer. Jakarta: Modern English Press

Salim, Peter

2006 The Contemporary English-Indonesia Dictionary Vol. Two M-Z. Jakarta: Media Eka Pustaka

Senhert, Keith w.

1981 Megendalikan Stres Dalam Rumah Tangga dan Pekerjaan. Bandung: Yayasan Kalam Hidup

Soedarsono, H. Soemarno

2005 Membangun Kembali Jati Diri Bangsa. Jakarta: Elek Media Komputindo

Tenney, Merrill C.

2000 Survei Perjanjian Baru. Malang: Gandum Mas

Tulluan,Ola

1999 Introduksi Perjanjian Baru. Malang: Departemen Literatur YPPII

Tim Penyusun

1988 Kamus Besar Bahasa Indonesia. Jakarta: Balai Pustaka

Tong, Stephen

2001 Hidup Kristen Yang Berbuah. Surabaya: Lembaga Reformed Injili Indonesia

Thoha, Miftah

1993 Kepemimpinan dan Manajemen. Jakarta: PT Raja Grafindo Persada

Tomatala, Yakob

2012 Kepemimpinan Yang Dinamis. Malang: Gandum Mas

Warren, Rick

2012 The Purpose Driven Life. Malang: Gandum Mas 
W.E. Vine, Merril F. Unger, William White, Jr.

1984 Vine's Complete Expository Dictionary of Old and New Testament Words. Nashville: Thomas Nelson Publishers

1998 Kamus Besar Bahasa Indonesia. Jakarta: Departemen Pendidikan dan Kebudayaan R.I.

1990 Kamus Besar Bahasa Indonesia. Jakarta: Departemen Pendidikan dan Kebudayaan Balai Pustaka

www.KristenSkeptis.com, "Hamba Tuhan Bermasalah”, (tanggal 11 Februari 2011), 4

http://en.wikipedia.org/wiki/J.F.C 